\title{
Assessing The Bioconcentration of Heavy Metals in Nypa Palm (Nypa fruticans (Wurmb) From Selected Mangrove Forests in Rivers State, Nigeria
}

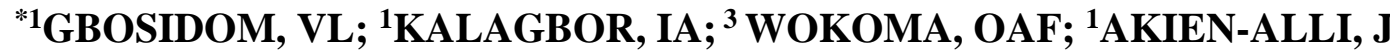 \\ ${ }^{* 1}$ Department of Science Laboratory Technology, Kenule Saro-Wiwa Polytechnic, Bori, Rivers State, Nigeria. \\ ${ }^{2}$ Department of Biology, Ignatius Ajuru University of Education, Port Harcourt, Nigeria. \\ *Corresponding Author Email: gbosidom.victor@kenpoly.edu.ng \\ Other Authors Email: okoriwokoma@yahoo.com; Kalagbor.ihesinachi@kenpoly.edu.ng; jobrigs@yahoo.com
}

\begin{abstract}
The bioconcentration of $\mathrm{Pb}, \mathrm{Zn}, \mathrm{Cd}, \mathrm{Cr}$ and $\mathrm{Ni}$ in tissues of Nypa palm (Nypa fruticans) was investigated during wet and dry seasons from selected mangrove forests, using the randomized complete block design. Soil and plant samples were randomly collected from plant dominated growth stations and analyzed for heavy metal content using the Perkin Elmer Analysts 200 Atomic Absorption Spectrophotometer (AAS). The results obtained showed the bio-transfer factors of heavy metals at wet season as $\mathrm{Pb}(1.08 \mathrm{mg} / \mathrm{kg}), \mathrm{Zn}(1.42 \mathrm{mg} / \mathrm{kg}), \mathrm{Cd}(6.14 \mathrm{mg} / \mathrm{kg}), \mathrm{Cr}(0.56$ $\mathrm{mg} / \mathrm{kg}) \mathrm{Ni}(0.90 \mathrm{mg} / \mathrm{kg})$ and dry season as $\mathrm{Pb}(0.86 \mathrm{mg} / \mathrm{kg}), \mathrm{Zn}(1.15 \mathrm{mg} / \mathrm{kg}), \mathrm{Cd}(5.44 \mathrm{mg} / \mathrm{kg}), \mathrm{Cr}(0.66 \mathrm{mg} / \mathrm{kg}), \mathrm{Ni}$ $(1.12 \mathrm{mg} / \mathrm{kg})$. The result further showed the bio-translocation factors of the metals at wet seasons as $\mathrm{Pb}(0.59 \mathrm{mg} / \mathrm{kg})$, $\mathrm{Zn}(0.76 \mathrm{mg} / \mathrm{kg}), \mathrm{Cd}(3.25 \mathrm{mg} / \mathrm{kg}), \mathrm{Cr}(0.22 \mathrm{mg} / \mathrm{kg}), \mathrm{Ni}(0.54 \mathrm{mg} / \mathrm{kg})$ and dry season as $\mathrm{Pb}(0.64 \mathrm{mg} / \mathrm{kg}), \mathrm{Zn}(1.03 \mathrm{mg} / \mathrm{kg})$ $\mathrm{Cd}(3.07 \mathrm{mg} / \mathrm{kg}), \mathrm{Cr}(0.24 \mathrm{mg} / \mathrm{kg}), \mathrm{Ni}(0.61 \mathrm{mg} / \mathrm{kg})$ respectively. Findings indicate the study plant as a hyper accumulator of $\mathrm{Ni}, \mathrm{Cd}$ and $\mathrm{Zn}$, and non-hyper accumulator of $\mathrm{Cr}$ and $\mathrm{Pb}$. It is thus recommended that $N$. fruticans be utilized for phytoremediation of $\mathrm{Ni}, \mathrm{Cd}$ and $\mathrm{Zn}$ in polluted mangrove ecosystem.
\end{abstract}

\section{DOI:https://dx.doi.org/10.4314/jasem.v25i9.17}

Copyright: Copyright (C) 2021 Gbosidom et al. This is an open access article distributed under the Creative Commons Attribution License (CCL), which permits unrestricted use, distribution, and reproduction in any medium, provided the original work is properly cited.

Dates: Received: 09 May 2021; Revised: 12 August 2021; Accepted: 12 September 2021

Key words: Heavy metal, Bioconcentration, Accumulation, Phytoremediation, Bio-transfer factor, Biotranslocation factor, Mangrove.

Globally, Nypa fruticans is identified as an integral component of the Asian mangrove forest whose distribution cuts across Europe, Africa and America (Duke, 2006; Dransfield et al., 2008). The plant was introduced to Cameroon and Nigeria in the African sub region from the Singapore Botanical Gardens in South East Asia in 1906 (Tuley,1995), from where it spread and naturalized in Panama and Trinidad, South America (Dransfield et al., 2008). The introduction to Nigeria was for the purpose of stabilizing the coastline against erosion (Udoidiong and Ekwu, 2011). This mangrove species after establishment has spread west ward across the region to Ondo State, invading expands of land, displacing the valuable endemic mangrove species. The trend of displacement cuts across the Niger Delta of Nigeria and Cameroon forming mono specific stands that compete against the native mangrove species (Saenger et al., 1995). The adaptation of the plant to its environment is due to the possession of underground prostrate rhizomes that branch dichotomously and from which young plants develop by vegetative propagation, thus forming extensive stands that are closely packed together (Teo et al., 2010). They also possess root systems that are extensive and capable of resisting swift water current
(Percival and Womersley, 1979). Nypa fruticans strive well in calm mangrove ecosystem with high inflow of fresh water (Tomlinson, 1986), and where sediments from the sea are deposited forming clay soil with brackish water and anaerobic condition (Rozainah and Aslezaeim, 2010). They propagate by means of viviparous germination (Tomlinson, 1986), while the seeds are dispersed and deposited inlands as far as the tide can reach. Niger Delta of Nigeria is noted for the production of light crude, with associated adverse negative impacts on mangrove forest (Duke et $a l ., 2000)$. The nature of mangrove forest devastation from anthropogenic activities has resulted to its classification as one of the forests with extremely rapid rate of depletion (FAO, 2005). Beside environmental impact of crude oil, other sources of heavy metals include discharges from industrial and municipal waste waters, storm, run-off, dust deposition, mine discharge and waste incineration (Cheng et al., 2009; Besser et al., 2009). Heavy metals and sewage constitute a major threat to mangrove forest (Agoramoorthy et al., 2008), and the understanding of varying concentrations of heavy metals, the nature of distribution coupled with their relative toxicity and persistence in the environment 
has bestowed it as a priority pollutant for environmental management globally (Don- Pedro et al., 2001). Mangrove soils have been shown to possess high capacity of retaining heavy metals which are taken up by plants (Machando et al., 2002). Studies have also shown that wetland plants possess the capacity for accumulation of heavy metals in their tissues (Yadav and Chandra, 2011). Such plants accumulate high levels of pollutants in their tissues above that of the contaminated media (Erakhrumen, 2014). Bert et al. (2003) identified three categories of plants that grow in contaminated sites as tolerant, indicator and hyper accumulators. While tolerant plants successfully grow in environment with high concentrations of pollutants that poison other plants, hyper accumulator plants take up these pollutants and store them in various tissues without harmful effect on their growth. Indicator plants grow and subsist in the environment with high concentrations of pollutants. Studies have shown that Nypa fruticans possesses high tolerance for $\mathrm{Cr}$ and $\mathrm{Zn}$ toxicity than Rhizophora racemosa (Gbosidom, et al., 2017). In their study; it was shown that $\mathrm{Zn}$ levels significantly influenced the growth and distribution of Nypa fruticans. Plants which have the tolerance and capacity to take up trace elements from contaminated soils are being used for phytoremediation (Mery et al., 2011). Nirmal et al. (2011) in their study on the assessment of the accumulation potential of $\mathrm{Pb}, \mathrm{Zn}$ and $\mathrm{Cd}$ by Avicinnia marina in Vamleshwar mangrove of Gujarat in India, reported that $A$. marina possessed the capacity to take up $\mathrm{Zn}$ and $\mathrm{Cd}$ through their roots, accumulating them in the leaves without showing any sign of injury. It was also observed that the roots of the plant accumulated high concentration of the metals with the exception of Cd. Also, in studying the accumulation and partitioning of $\mathrm{As}, \mathrm{Cd}, \mathrm{Cr}, \mathrm{Cu}, \mathrm{Hg}, \mathrm{Pb}$ and $\mathrm{Zn}$ in the three estuarine wetlands in the Hainan Island of China, Qiu et al. (2011) reported that $\mathrm{Pb}$ was found in the branches of the different mangroves studied. Apart from the use of hyper accumulator plants to extract heavy metals from the environment, non-hyper accumulators accumulate higher concentrations of heavy metals in their roots than the shoots (McGrath et al., 2001). In a bid to solve the environmental problems associated with heavy metals in mangrove forest through phytoremediation, this study was designed to evaluate the bio concentration of heavy metals in Nypa fruticans and its application in phytoremediation.

\section{MATERIALS AND METHODS}

Study Area: The study area stretches from Longitude $7^{0} 05^{\prime} 00^{\prime \prime}$ E through Longitude $7^{0} 30$ ' 30 " E and latitude $4^{0} 45^{\prime} 30^{\prime \prime} \mathrm{N}$, encompassing communities such as Kono (station 1), Bomu (station 2), Ogu (station 3) and Port
Harcourt (station 4). These are the areas enlisted for the study.

Experimental Design: The randomized complete block design (RCBD) method consisting of 4 stations was used for the study.

Field Sampling: Field sampling was done in two seasons. The wet season sampling was undertaken from July to August 2015, while dry season sampling was done from January to February, 2016.

Soil and Plant Sampling: Soil samples were collected randomly at $0-30 \mathrm{~cm}$ closer to the roots of Nypa fruticans at their dominant growth area in three replications each using soil auger. The above-ground (Leaves and stems) and below-ground (roots) samples of $N$. fruticans were randomly collected from the four study stations in three replications each, using sharp knife and hoe. Soil and plant samples were stored in sterile cellophane bags, labeled with sample codes for easy identification and transported in plastic coolers to the laboratory for the evaluation of heavy metals.

Sample Preparation: Soil and plant samples were prepared at the Chemistry Laboratory of Science Laboratory Technology in Ken Saro-Wiwa Polytechnic, Bori. Soil samples were dried in the hot air oven (model $\mathrm{T} 5028$ ) at $100^{\circ} \mathrm{C}$ and crushed into powdered form using porcelain mortar and pestle, after which samples were sieved using skitter. The prepared samples were then stored in clean cellophane bags and labeled according to their respective to sample identity.

The above ground tissues (leaves/stem) and the below ground tissues (root) samples were dried in the oven at $150^{\circ} \mathrm{C}$, as separate samples using porcelain mortar and pestle. Pulverized samples were stored in clean cellophane bags and labeled according to sample identity.

Digestion of Samples: Pulverized soil samples were digested by weighing out $1 \mathrm{~g}$ each, using analytical weighing balance (model TH1000) into respective Pyrex beakers and labeled according to sample identity. To each sample, $5 \mathrm{ml} \mathrm{HNO}_{3}(70 \%$ v/v) was added, followed by $5 \mathrm{ml} \mathrm{HCLO}_{4}(70 \% \mathrm{v} / \mathrm{v})$ and then $10 \mathrm{ml} \mathrm{HF}(48 \% \mathrm{v} / \mathrm{v})$. The resultant solution was subjected to heating, using the heating mantle (model MY 6403) until the sample was dry. The residue was allowed to cool. After cooling, the residue was dissolved in $5 \mathrm{ml} \mathrm{HCL}(36 \% \mathrm{v} / \mathrm{v})$ and $20 \mathrm{ml}$ distilled water after which the digested samples were filtered, washed using cotton wool into different prelabeled $100 \mathrm{ml}$ volumetric flask. The digested samples were 
made up to $100 \mathrm{ml}$ by addition of distilled water. The above procedure enhanced the dissolution of the soil silicate matrix consequently yielding total digestion. The digested samples were stored in sample bottles and labeled for heavy metal analysis.

Plant samples were digested by weighing $2 \mathrm{~g}$ of the pulverized samples, using analytical balance (modelTH 1000) into $250 \mathrm{ml}$ beakers. To each beaker containing samples, $132 \mathrm{ml}$ of distilled water was added. Also, $5 \mathrm{ml} \mathrm{HNO}_{3}, 10 \mathrm{ml}$ of $\mathrm{H}_{2} \mathrm{SO}_{4}$ and $2 \mathrm{ml} \mathrm{H}_{2} \mathrm{O}_{2}$ were added and made up to $150 \mathrm{ml}$ using distilled water. The resultant mixture was heated using heating apparatus in a fume cupboard till the volume was reduced to about $50 \mathrm{ml}$.The digested sample was allowed to cool, then filtered and washed using cotton wool into a $100 \mathrm{ml}$ volumetric flask and made up to $100 \mathrm{ml}$. Samples were stored in sample bottles and labeled according to samples identity for heavy metal analysis.

Heavy Metal Analysis: Heavy metal content of soil and plant tissues were determined using the Perkin Elmer Analysts 200 Atomic Absorption Spectrophotometer (AAS). Cr, Nickel, $\mathrm{Cd}, \mathrm{Pb}$ and $\mathrm{Zn}$ were determined based on their respective wave lengths. A certified standard stock solution of $1000 \mathrm{ppm}$ was prepared for the analysis, from which working standards were prepared based on the linearity range of each metal. Compressed air was used as oxidant while acetylene gas was used as fuel gas. To set zero absorbance, distilled water was used as a blank while the instrument was optimized based on the characteristics of the respective metals to be determined. Calibration curves were prepared using 4 to 5 working standards for each metal. The concentration of samples was read by the AAS in ppm and printed.

Determination of Bio Transfer and Translocation Factor (TF): Bio transfer factor of pollutants were quantified according to Kumar et al., (1995) method using the formula

Bio transfer factor $(\mathrm{BTF})=\frac{C_{\text {biota }}}{C_{\text {soil }}}$,

Where $\mathrm{C}_{\text {biota }}$ is the total concentration of metal or pollutant in biota, while $\mathrm{C}_{\text {soil }}$ is the total concentration of metal or pollutant in the soil.

The translocation factor (TF) of pollutants in plant samples were estimated using the equation (2) by (Barman et al., 2000; Gupta et al., 2008):

$\mathrm{TF}=\frac{\text { Concentration of pollutants in shoot }}{\text { Concentration of pollutants in root }}$

\section{RESULTS AND DISCUSSION}

Bio Transfer Factor of Heavy Metals: The result of wet season means bio transfer factor (BTF) of $\mathrm{Cr}$ in $N$. fruticans tissues presents a trend of station $4>$ station $1>$ station $3>$ station 2 . The mean TF for the four stations was $0.56 \mathrm{mg} / \mathrm{kg}$. These results did not indicate statistical differences between the mean $\mathrm{TF}$ of $\mathrm{Cr}$ at the study stations at $\mathrm{p}=0.05$ (Figure 1). The dry season mean transfer factor (BTF) of Cr in $N$. fruticans tissues was observed with a trend showing that station $4>$ station $1>$ station $3>$ station 2 , with the mean TF of the study stations as $0.66 \mathrm{mg} / \mathrm{kg}$. The above results were not statistically different between the stations at $\mathrm{p}=0.05$ (Figure 1). The result of wet season transfer factor of $\mathrm{Cd}$ in $N$. fruticans at the study stations indicated the trend of station $2>$ station $1>$ station 3 $>$ station 4 , while the mean transfer factors of the four study stations showed the value of $6.14 \mathrm{mg} / \mathrm{kg}$. The above result had no statistical differences in transfer factors of $\mathrm{Cd}$ at $\mathrm{p}=0.05$ (Figure 2). At dry season, the trend for mean transfer factor is station $3>$ station $4>$ station $2>$ station 1 , with a mean transfer factor of 5.44 $\mathrm{mg} / \mathrm{kg}$ for the four study stations. There were no statistical differences in bio transfer factors at $p=0.05$ (Figure 2). The result of wet season means bio transfer factor (BTF) of Ni in $N$. fruticans growth soil and plant showed the trend of station $3>$ station $1>$ station $4>$ station 2 . The result further showed the mean transfer factor of the four study stations as $0.90 \mathrm{mg} / \mathrm{kg}$. From these results there is statistical difference between stations 1 and 3, 2 and 3, and between station 3 and 4 at $\mathrm{p}=0.05$ (Figure 3). At dry season, mean transfer factor of $\mathrm{Ni}$ showed the trend of station $1>$ station $3>$ station $4>$ station 2 , with the four study stations showing a mean transfer factor of $1.12 \mathrm{mg} / \mathrm{kg}$. Furthermore, there is statistical differences between stations 1 and 2, 1 and 4, and between station 2 and 3 at $\mathrm{p}=0.05$ respectively (Figure 3 ). The result of wet season mean bio transfer factor (BTF) of $\mathrm{Pb}$ in $N$. fruticans tissues is observed with a trend of station $3>$ station $4>$ station $1>$ station 2 . The mean $\mathrm{TF}$ of $\mathrm{Pb}$ of the four study stations as $1.08 \mathrm{mg} / \mathrm{kg}$. These results showed no statistical differences in mean transfer factor of $\mathrm{Pb}$ at $\mathrm{p}=0.05$ (Figure 4). The dry season results produced the mean transfer factor of trend of station $4>$ station $3>$ station $1>$ station 2 , with a TF of $0.86 \mathrm{mg} / \mathrm{kg}$ for the study stations. These results displayed statistical differences in mean transfer factors of $\mathrm{Pb}$ between the stations at $\mathrm{p}=0.05$. The LSD result further showed statistical difference between stations 2 and 3 and between station 2 and 4 at $p=0.05$ respectively (Figure 4). The wet season mean transfer factor of $\mathrm{Zn}$ in $N$. fruticans growth soil and plant tissues exhibits the trend showing that station $4>$ station $3>$ station $2>$ station 1 . The mean transfer factor of $\mathrm{Zn}$ of the four study stations as $1.42 \mathrm{mg} / \mathrm{kg}$.

GBOSIDOM, VL; KALAGBOR, IA; WOKOMA, OAF; AKIEN-ALLI, J 


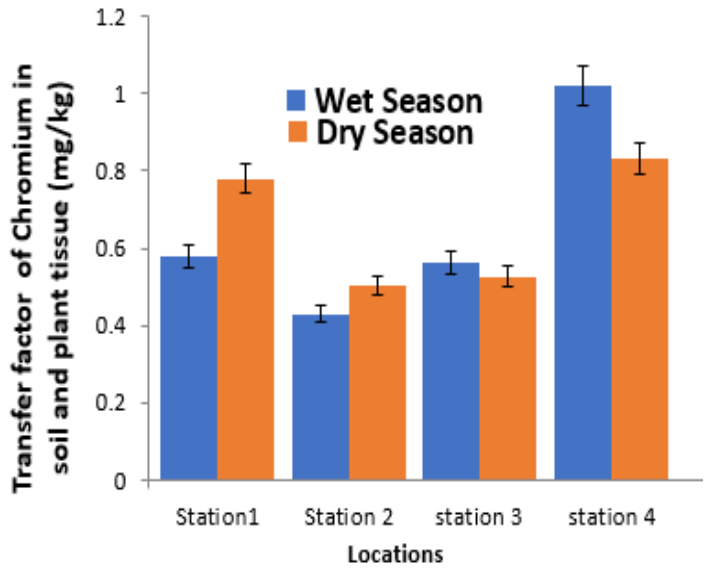

Fig. 1: Bio Transfer Factor of $\mathrm{Cr}$ in N. fruticans

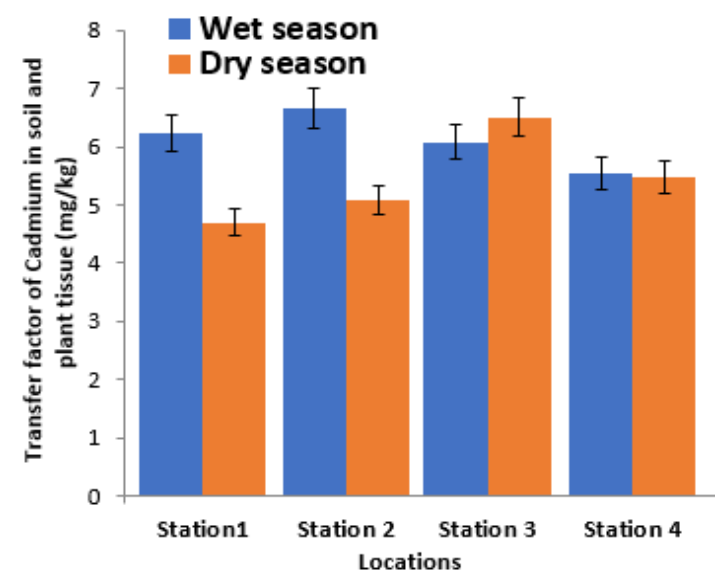

Fig. 2: Bio Transfer Factor of Cd N. fruticans

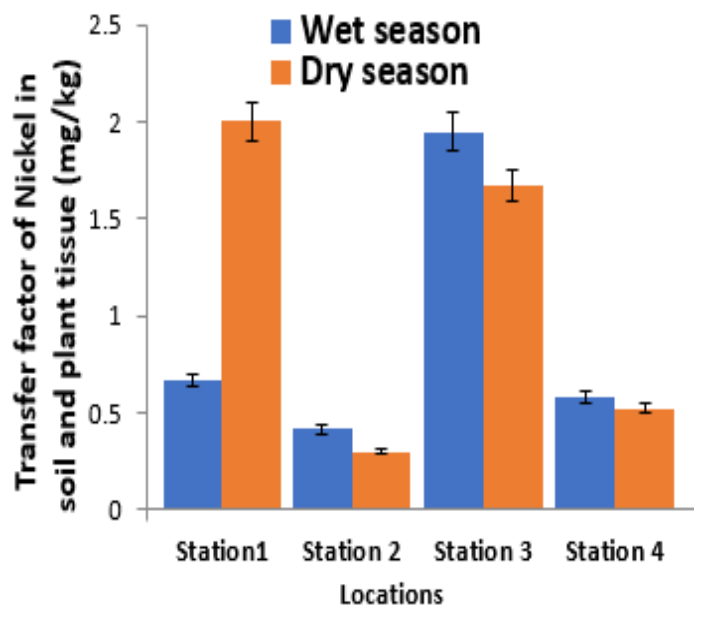

Fig. 3: Bio Transfer Factor of $\mathrm{Ni}$ in N. fruticans

There were no significant differences in transfer factors based on stations at $p=0.05$ (Figure 5). At dry season, the results were observed with a trend showing that $\mathrm{TF}$ of station $3>$ station $4>$ station $2>$ station 1 , with the mean transfer factor of $\mathrm{Zn}$ for the four study stations $1.15 \mathrm{mg} / \mathrm{kg}$. These results were statistically different based on stations at $\mathrm{p}=0.05$. The LSD result on the mean transfer factor of $\mathrm{Zn}$ showed statistical differences between stations 1 and 3,1 and 4, 2 and 3, and between station 2 and 4 at $\mathrm{p}=0.05$ respectively (Figure 5).

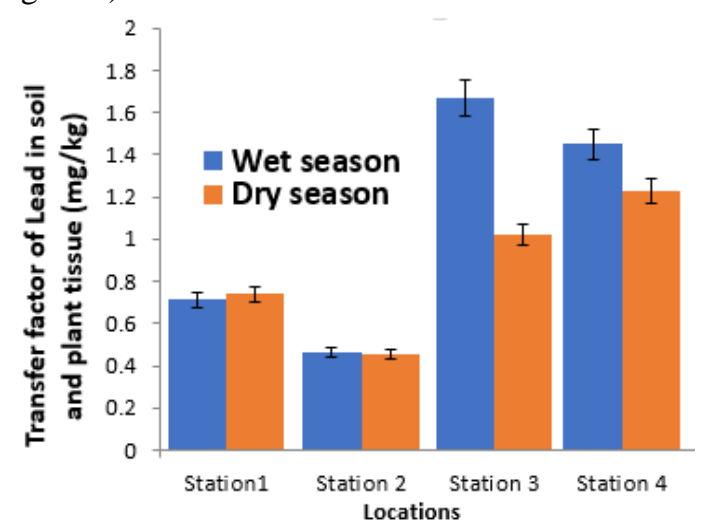

Fig. 4: Bio Transfer Factor of $\mathrm{Pb}$ in N. fruticans

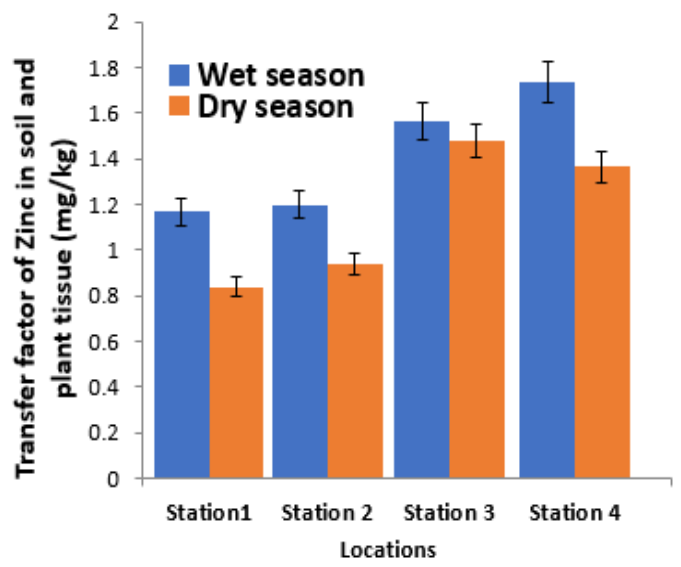

Fig. 5: Bio Transfer Factor of $\mathrm{Zn}$ in N. fruticans

Translocation Factor Of Pollutants: The wet season result of mean translocation factor (TF) of $\mathrm{Cr}$ in the root and shoot tissues of $N$. fruticans showed the trend of station $2>$ station $3>$ station $1>$ station 4 . The result also showed the mean translocation factor for the four study stations as $0.22 \mathrm{mg} / \mathrm{kg}$. The above result indicated statistical differences in $\mathrm{TF}$ of $\mathrm{Cr}$ in $N$. fruticans based on stations at $\mathrm{p}=0.05$. The LSD results showed statistical differences in Cr TF between stations 1 and 2, 2 and 3, and between station 2 and 4 at $\mathrm{p}=0.05$ respectively (Figure 6). At dry season, the mean translocation factor of $\mathrm{Cr}$ in root and shoot tissues of $N$. fruticans exhibited the trend of station 2 $>$ station $1>$ station $3>$ station 4 . The above result also showed the mean translocation factor of the four study stations as $0.24 \mathrm{mg} / \mathrm{kg}$. These results were statistically different based on stations at $p=0.05$. The LSD result further showed difference in Cr TF between stations 1 and 2, 2 and 3, and between station 2 and 4 at $p=0.05$ respectively (Figure 6). 


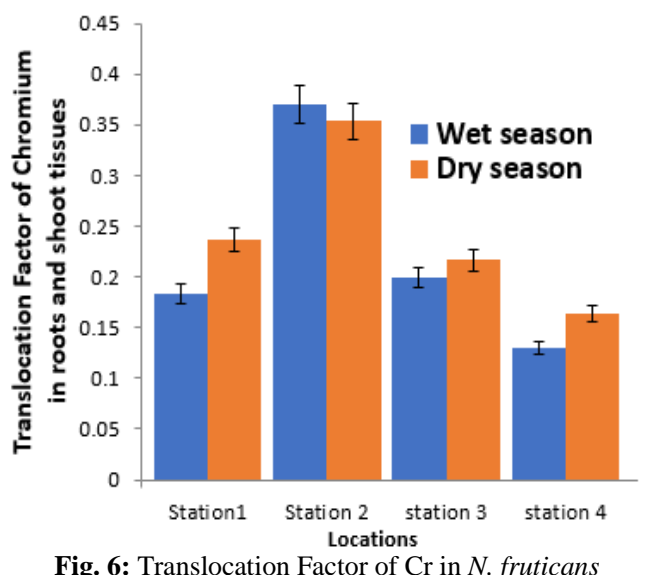

The study on wet season translocation factor of $\mathrm{Cd}$ in $N$. fruticans root and shoot was observed as station 1 $>$ station $2>$ station $4>$ station 3 . The mean translocation factor of the above four study stations was observed as $3.25 \mathrm{mg} / \mathrm{kg}$. These results were not statistically significant in terms of difference based on stations at $\mathrm{p}=0.05$ (Figure. 7). The dry season study followed the trend of station $1>$ station $2>$ station $4>$ station 3 in translocation factor of $\mathrm{Cd}$ in roots and shoots of $N$. fruticans. The results of mean translocation factor of the four study stations was observed as $3.07 \mathrm{mg} / \mathrm{kg}$. There were observed statistical differences between the mean $\mathrm{Cd}$ translocation factors based on stations at $p=0.05$. The LSD result further indicated statistical differences between stations 1 and 3, 2 and 3 and between station 3 and 4 at $\mathrm{p}=0.05$ (Figure. 7).

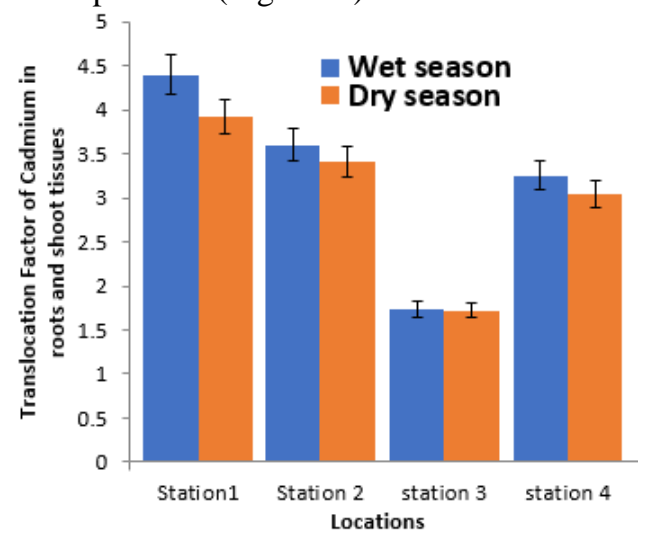

Fig. 7: Translocation Factor of Cd in N. fruticans

The result of wet season translocation factor of $\mathrm{Ni}$ in the root and shoot tissues of $N$. fruticans specified the trend of station $2>$ station $3>$ station $1>$ station 4 . The result also indicates the mean translocation factor of the four study stations as $0.54 \mathrm{mg} / \mathrm{kg}$. Furthermore, there were statistical differences in translocation factors based on stations at $p=0.05$. The LSD result clearly indicate statistical difference between stations
1 and 2, 1 and 3,2 and 3, 2 and 4, station 3 and 4 (Figure 8 ). The dry season study the displayed the trend of station $3>$ station $2>$ station $1>$ station 4 in translocation factor of $\mathrm{Ni}$, while the mean translocation factor of the four study stations amounted to $0.61 \mathrm{mg} / \mathrm{kg}$. Furthermore, these results were not statistically different at $\mathrm{p}=0.05$ (Figure 8).

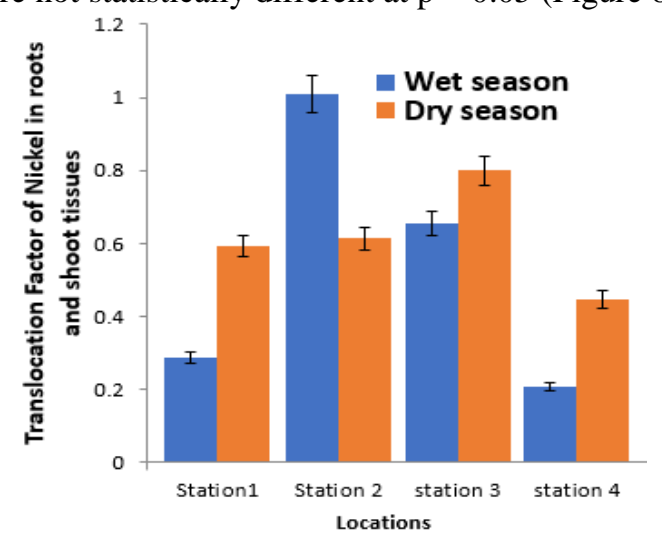

Fig. 8: Translocation Factor of Ni in N. fruticans

The wet season result of mean translocation factor (TF) of $\mathrm{Pb}$ in $N$. fruticans root and shoot tissues indicates a trend showing station $2>$ station $1>$ station $4>$ station 3. It was further observed that the mean TF of $\mathrm{Pb}$ at the four study stations was $0.59 \mathrm{mg} / \mathrm{kg}$. There were also statistical differences in mean translocation factor of $\mathrm{Pb}$ based on stations at $\mathrm{p}=0.05$. The LSD result further validate differences in mean translocation factor of $\mathrm{Pb}$ between stations 1 and 2, 1 and 3,2 and 3, and between station 2 and 4 at $p=0.05$ respectively (Figure 9). During the dry season, the result of mean translocation factor of $\mathrm{Pb}$ in $N$. fruticans root and shoot tissues was observed to indicate a trend of station $2>$ station $1>$ station $4>$ station 3 , while the mean translocation factor of the study stations was $0.64 \mathrm{mg} / \mathrm{kg}$. These results displayed statistical differences in mean translocation factor of $\mathrm{Pb}$ in $N$. fruticans root and shoot tissues at $\mathrm{p}=0.05$. The LSD result further indicate differences in mean translocation factor of $\mathrm{Pb}$ between stations 1 and 2, 1 and 3,2 and 3, 2 and 4, and between station 3 and 4 at $p=0.05$ respectively (Figure 9). The result of wet season study on translocation factor of $\mathrm{Zn}$ in root and shoot tissues of $N$. fruticans followed the trend of station $1>$ station $2>$ station $4>$ station 3 , while the mean translocation factor of the four study stations was observed as $0.76 \mathrm{mg} / \mathrm{kg}$. The above results were not statistical different based on stations at $p=0.05$ (Figure. 10). The result of dry season study indicated a trend showing translocation factor of station $1>$ station $2>$ station $3>$ station 4 . The mean translocation factor of the four study stations was 1.03 $\mathrm{mg} / \mathrm{kg}$. This result was not statistical different based on stations at $\mathrm{p}=0.05$ (Figure. 10). 


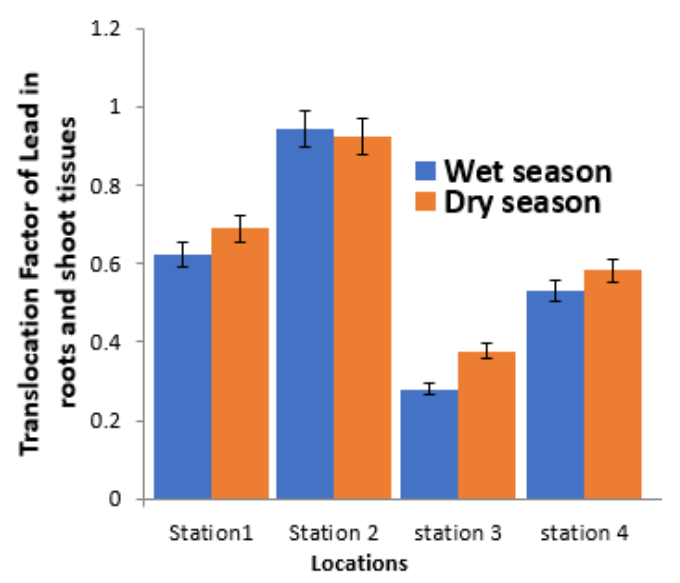

Fig. 9: Translocation Factor of $\mathrm{Pb}$ in $N$. fruticans

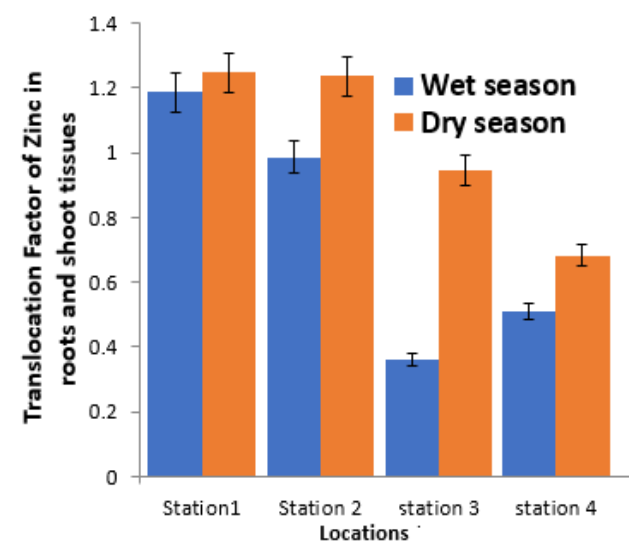

Fig. 10: Translocation Factor of $\mathrm{Zn}$ in $N$. fruticans

The study on comparison of pollutant accumulation in the tissues of $N$. fruticans exhibited different reactions. Results obtained from $\mathrm{Cr}$ uptake indicates that $N$. fruticans accumulated more $\mathrm{Cr}$ in root tissues than shoot tissues. The result further expressed significant difference in root tissues across study stations. There were also significant differences in shoot tissues across stations. The observed high concentration of $\mathrm{Cr}$ in the root tissues could be attributed to the low mobility and bioavailability of $\mathrm{Cr}$ to natural phytoextraction process as observed by Komerek et al., (2007). The results of Cr transfer factor (TF) did not show any statistical significance. However, the translocation factors were significant at 0.05 alpha levels with variability in least significant differences across the study stations. The results further indicated that the transfer and translocation factors were $<1.0$, an indication that $\mathrm{Cr}$ was mainly concentrated in the ground (root) tissues of the plant. These findings corroborate the report of McGrath et al. (2001) who showed that some plants accumulated higher concentrations of heavy metals in their roots than shoot tissues and thus referred to them as non-hyper accumulators. It can thus be inferred that $N$. fruticans possessed higher potentials for chromium accumulation in their root tissues. Similarly, Debargha et al. (2013) in their study observed low bioaccumulation factor for $\mathrm{Zn}, \mathrm{Cu}, \mathrm{Pb}$ and $\mathrm{Cr}$ in Avicennia officinalis with $\mathrm{TF}<1$, an observation which they interpreted as an indication that $A$. officinalis took up and translocate the above metals below the levels exhibited by hyper accumulators. The results obtained on $\mathrm{Ni}$ accumulation showed that $N$. fruticans accumulated more concentrations of $\mathrm{Ni}$ in their below ground (roots) tissues than the above ground (shoot) tissues, with significant differences across the study stations at $p<0.05$. The above finding contradicts the report of Pahalawattaarachchi et al. (2009) who observed that Nickel was concentrated in the shoots of Rhizophora macronata than in their roots. However, the finding was in tandem with those of Komerek et al. (2007) who observed high concentration of $\mathrm{Cr}$ in root tissues than shoot tissues. The findings supported the fact that plants species possess different accumulation potentials for different metals (Cheng, 2003). The study showed that the transfer factor of $\mathrm{Ni}$ in $N$. fruticans was $>1$, a finding that qualify $N$. fruticans as a hyper accumulator of Nickel. Earlier reports showed that hyper accumulators are not only tolerant for high concentration of pollutants but also exhibit bio concentration factor and translocation factor $>1(\mathrm{Ma}$ et al., 2001).

The results obtained on $\mathrm{Cd}$ accumulation showed that $N$. fruticans accumulated more concentrations of $\mathrm{Cd}$ in the above ground (shoot) tissues than the below ground (root) tissues. This result was significant across stations at $\mathrm{p}<0.05$. The above finding is in agreement with an earlier report by Pahalawattaarachchi et al. (2009) who observed high concentration of cadmium, zinc, Nickel and lead in the shoot of Rhizophora macronata than their roots. Similar observation was reported in Avicennia marina where cadmium was concentrated in leave tissues (Nirmal et al., 2011). The evaluated transfer and translocation factors of Cadmium in $N$. fruticans was $>$ 1.0. The above finding corroborates the report of $\mathrm{Ma}$ et al. (2001) who stated that plants that are tolerant to high concentration of pollutants exhibited bio concentration and translocation factors $>1$. Similarly, Erakhrumen, (2014) classified heavy metal accumulating plants as those heaving concentrated pollutants in their tissues above that of the contaminated media. It is thus inferred that $N$. fruticans is a hyper accumulator of cadmium. Results on lead $(\mathrm{Pb})$ accumulation in the tissues of $N$. fruticans showed higher accumulation in the below ground (root) tissues than the above ground (shoot) tissues. These concentrations were all significant at $\mathrm{p}<0.05$ 
across the study stations. The above observation is in line with the finding of Komerek et al. (2007) who reported the accumulation of heavy metals in root tissues and attributed it to the low mobility and bioavailability of such metals to natural uptake process by plants. Other corroborated reports on accumulation of metals in root tissues of plants include Pahalawattaarachchi at al., (2009) and Almasheer et al., (2014). The transfer factor of $\mathrm{Pb}$ in $N$. frusticans was observed to range between 0.86 and 1.08 , with translocation factors between 0.59 and 0.64. Both transfer and translocation factors were significant at $\mathrm{p}$ $<0.05$ across stations. Similar low bioaccumulation factor $<1$ was reported in Avicennia officinalis, which was interpreted as an indication that $A$. officinalis take up $\mathrm{Pb}$ and translocate them below the levels exhibited by hyper accumulators. It can thus be inferred that $N$. fruticans is a non-hyper accumulator of $\mathrm{Pb}$. Evaluation of zinc ( $\mathrm{Zn}$ ) accumulation in the tissues of $N$. fruticans showed that $N$. fruticans as an accumulator of $\mathrm{Zn}$ in the below ground (root) tissues, with a transfer factor $>1.0$. This result was significant across stations at $\mathrm{p}<$ 0.05 . The result of the translocation factor was $>1.0$, however the result was not statically significant across stations. The above findings qualify $N$. fruticans root as a non-hyper accumulator of $\mathrm{Zn}$, which is in line with McGrath et al. (2001) who reported that non-hyper accumulator plants accumulate higher concentrations of heavy metals in their roots than the shoots. Root tissues have also been shown to accumulate higher concentrations of most metals than the above ground tissues (Pahalawattaarachchi et al., (2009) and Almasheer et al., (2014). The high accumulation of metals in root tissues was associated with low mobility and bioavailability of the metals to natural phytoextraction process (Komerek et al., 2007).

Conclusion: The bioconcentration of heavy metals in $N$. fruticans was investigated in this study. Findings consequently established the study plant as a nonhyper accumulator of $\mathrm{Cr}$ and $\mathrm{Pb}$ in root tissues, and hyper accumulator of $\mathrm{Zn}$ and $\mathrm{Ni}$ in root tissues and $\mathrm{Cd}$ in shoot tissues. It is therefore recommended that $N$. fruticans can be used for the phytoremediation of $\mathrm{Ni}$, $\mathrm{Cd}$ and $\mathrm{Zn}$ for which they show good potential for accumulation.

\section{REFERENCES}

AGAROMOORTHY, G; CHEN, EA; HSU, MJ (2008). Threat of heavy metal pollution in halophyte and mangrove plant of Tamil Nadu, India. Environ Pollut, 155(2): 320- 326.

ALMAHASHEER, HB; AL-TAISAN, WA; MOHAMAD, MK (2014). Metals accumulation in Grey Mangrove (Avicennia marina (Forsk) Vierh) inhabiting Tarut Bay, Eastern Saudi Arabia. J Agricul Sci, 6(1): 137- 149.

BARMAN, SC; SAHU, RK; BHARGAVA, SK; CHATTERJEE, C (2000). Distribution of heavy metals in wheat mustard and weed grains irrigated with industrial effluents. Bullet Environ Contam and Toxicol, 64: 489-496.

BERT, V; MEERTS, P; SAUMITOU-LAPRADE, P; SALIS P; GRUBER, W; VERBRUGGEN, W (2003). Genetic basis of Cd tolerance and hyper accumulation in Arabidopsis halleri. Plant soil, 249:9-18.

BESSER, J; BRUMBAUGH, W; ALLERT, A; POULTRON, B; SCHMITT, C; INGERSOU, C (2009). Ecological impacts of land mining on Ozark streams: toxicity of sediment and pure water. Ecotoxicol Environ Safty, 72: 516-526.

CHENG, H; HU, Y; LUO, J; XU, B; ZHAO, J (2009). Geochemical processes controlling fate and transport of Arsenic in acid mine drainage (AMD) and natural system. J Haz Materials, 656: 13-26.

CHENG, S (2003). Heavy metals in plants and phytoremediation. Environ SciPoll Res, 10(5):33540.

DEBARGHA, C; SUBHAJIT, B; JAYJIT, M; SANTRA, SC (2013). Heavy metal pollution and phytoremediation potential of Avicinnia officinalis L. in the southern Coast of Hoogly estuarine system. Int J Environ Sci, 3(16):2291-2303.

DON-PEDRO, KN; OYEWO, EO; OTITOLOJU, AA (2001). Trend of heavy metal concentration in Lagos Lagoon ecosystem, Nigeria. West Afric $J$ Appl Ecol, 5:103-114.

DRANSFIELD, J; UHL, NW; ASMUSSAN, CB; BAKER WJ; HARLEY, MM; LEWIS, CE (2008). Genera palmarum: The Evolution and Classification of Palms. Royal Botanic Gardens, Kew. 732.

DUKE, N (2006). Australia Mangroves: The Authoritative Guide to Australia's Mangrove Plants. University of Queensland, Queensland, 200.

DUKE, NC; BURNS, KA; SWANNELL, RPJ; DALHAUS, O; RUPP, RJ (2000). Dispersant use and a bioremediation strategy as alternate means of reducing impacts of large oil spills on mangroves: the Gladstone field trails. Mar pollut Bull, 41(712): 403-412. 
ERAKHRUMEN, AA (2014). Potential of Rhizophora racemosa for Bio-indication and Dendro remediation of heavy metal contamination in a mangrove forest, Ondo State Nigeria. Nig J Agric, Food Environ, 10(4): 1-5

FAO (Food and Agricultural Organization) (2005). National mangrove to combat Desertification, University Press Oxford.

GBOSIDOM, V. L; OBUTE, GC; TANEE, FBG (2017). Evaluation of heavy metal levels and the distribution of Rizophora racemosa and Nypa fruticans in Niger Delta mangrove forest, Nigeria. J Nat Sci Res, 7(2):9-16.

GUPTA, S; NAYEK, S; SAHA, RN; SATPATI, S (2008). Assessment of heavy metal accumulation in macrophyte, agricultural soil and crop plants adjacent to discharge zone of sponge iron factory. Environ Geol, 55:731-739.

KOMAREK, M; TLUSTOS, P; SZAKOVA, J; CHRASTNY, V; BALIK, J (2007). The role of Fe and $\mathrm{Mn}$ oxides during EDTA-enhanced phytoextraction of heavy metals. Plant, Soil Environ, 53(5): 216- 224.

MA, LQ; KOMAR, KM; TU, C; ZHANG, W; CAI, Y; KENNELLEY, ED (2001). A fern that accumulates arsenic. Nature, 409: 579.

MACHANDO, WE; SILVA-FILHO, V; OLIVEIRA, RRLD (2002). Trace metal retention in mangrove ecosystems in Guanabara Bay, SE Brazil. Mar Pollut Bullet, 44:1277-1280.

MCGRATH, SP; ZHAO, FJ; LOMBI, E (2001). Plant and Rhizosphere processes involved in phytoremediation of metal contaminated soil. Plant Soil, 232: 207-214.

MERY, M; ORNELLA, A; SANDRO, B; AGNES, G; CARMELA, LG; EDOARDO, M (2011). Accumulation of heavy metals from contaminated soil to plants and evaluation of soil remediation by vermiculite. Chemosphere, 82(2): 169- 178.

NIRMAL KUMAR, IJ; SAJISH, PR; NIRMAL KUMAR, R; BASIL, G; SHAILENDRA, V (2011). An assessment of the accumulation potential of $\mathrm{Pb}, \mathrm{Zn}$ and $\mathrm{Cd}$ by Avicennia marina
(Forssk Vierh) In: Vamleshwar mangroves, Gujarat, India. Notulae Sci Biologicae, 3(1): 36-40.

PAHALAWATTAARACHCHI, V; PURUSHOTHAMAN, CS; VENNILA, A (2009). Metal phytoremediation potential of Rhizophora mucronata (Lam). Ind J Mar Sci, 38(2): 178-183.

PERCIVAL, M; WOMRSLEY, JS (1979). Floristic and Ecology of the mangrove vegetation of Papua New Guinea. A companion volume to the Handbook Flora of Papua New Guinea. Papua New Guinea Herbarium, Department of Forest, Div, of Botany, Lae, Papua New Guinea Botany Bulletin No. 8.

QIU, Y; LIN, D; LIU, J; ZENG, EY (2011). Bioaccumulation of trace metals in farmed fish from South China and potential risk assessment. Ecotoxicol Environ Safety, 74: 284-293.

ROZAINA, MZ; ALSLEZAEIN, N (2010). A demographic study of a mangrove palm, Nypa fruticans. Scientific Research and Essays, 5(24):3896-3902.

SAENGER, P; BELLAN, MF (1995). The mangrove vegetation of Atlantic coast of Africa. University Toulouse press, Toulouse.

TOE, S; ANG, W.F; LOK, AFL; KURUKULASURIYA, B. R; TAN, HTW (2010). The status and distribution of Nipa palm, Nypa fruticans WURMB (ARACACEAE), in Singapore, $3: 45-52$

TOMLINSON, PB (1986). The Botany of Mangroves. Cambridge University press.

TULEY, P (1995). The Palms of Africa. Trendrine Press, Cornwall 189.

UDOIDIONG, OM; EKWU, AO (2011). Nypa Palm (Nypa fruticans Wurmb) and the intertidal epibenthic macro fauna east of the Imo River Estuary, Nigeria. World Appl Sci J, 14(9): 13201330

YADAV, S; CHANDRA, R (2011). Heavy metals accumulation and Eco physiological effect on Typha angusifolia L and Cyperus esculentus L. growing in distillery and tannery effluent polluted natural wetland site, Unnao, India. Envision Earth Science, 62:1235-1 